Estudios de

lingüística inglesa aplicada

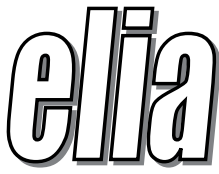

\title{
PRE-SERVICE PRIMARY SCHOOL TEACHERS' REFLECTIONS ON EFL STUDENTS' AWARENESS OF GRAMMATICAL FORMS IN ONLINE COMMUNICATION
}

\section{REFLEXIONES DE MAESTROS DE LA ESCUELA PRIMARIA ANTES DEL SERVICIO SOBRE EL CONOCIMIENTO DE LOS ESTUDIANTES DE FORMAS GRAMÁTICAS EN LA COMUNICACIÓN EN LÍNEA}

\section{Oleksandr Kapranov}

Western Norway University of Applied Sciences, Norway

oleksandr.kapranov@hvl.no

DOI: http://dx.doi.org/10.12795/elia.2018.i18.08

This article involves an empirical study of pre-service primary school teachers' essays on primary school students' awareness of grammatical forms of English as a Foreign Language (EFL) in online communication. 10 pre-service primary school teachers (hereafter - participants) were matched with their respective control group of 10 non-teacher students enrolled in the same EFL course at a large university in Norway. The specific aim of the study was to analyse the participants' reflective essays and to juxtapose them with the essays written by the controls in order to reveal possible differences between the two groups. The participants' and the respective controls' reflective essays about primary school students' awareness of EFL grammatical forms in online communication in English were further analysed by means of a mixed-method design comprised of a 
quantitative analysis with the computer software program WordSmith (Scott, 2012) and a qualitative framing analysis. The results of data analysis indicate that the frames found in participants' reflective essays fall within 6 categories, namely "Attention to Grammar", "Encouragement", "Individual Differences", "Informal Language", "No Attention to Grammar", and "Subjective Opinion". These findings are further discussed in the article.

Key words: English as a Foreign Language (EFL), grammatical awareness, online communication, primary school, pre-service teachers' reflections

El presente artículo incluye una investigación empírica de las reflexiones de los maestros de escuela primaria antes del servicio sobre la conciencia que los estudiantes de primaria tienen de las formas gramaticales del inglés como lengua extranjera (EFL) en la comunicación en línea. 10 maestros de escuela primaria antes del servicio (en adelante, participantes) se emparejaron con su grupo de control respectivo de 10 estudiantes no docentes matriculados en el curso de EFL en una universidad grande en Noruega. El objetivo de la investigación fue analizar las reflexiones de los participantes y yuxtaponerlas con las reflexiones del grupo de control para revelar posibles diferencias entre los dos grupos. Las reflexiones de los participantes y de los respectivos controles relacionadas con el enfoque de los alumnos de primaria sobre las formas gramaticales EFL en la comunicación en línea en inglés se investigaron mediante un diseño de métodos mixtos compuesto por un análisis cuantitativo en el programa de software informático WordSmith (Scott, 2012) y un análisis cualitativo de encuadre. Los resultados del análisis de datos indicaron que los participantes enmarcan sus ensayos reflexivos mediante los marcos "Atención a la gramática", "Diferencias individuales", "Ánimo”, "Sin atención a la gramática", "Lenguaje informal" y "Opinión subjetiva". Estos hallazgos se discuten más a fondo en el artículo.

Palabras clave: conciencia gramatical, comunicación online, inglés como lengua extranjera (EFL), escuela primaria, reflexiones de los maestros de escuela primaria antes del servicio

ELIA 18, 2018, pp. 183-212～DOI: http://dx.doi.org/10.12795/elia.2018.118.08 


\section{Introduction}

This article involves a mixed-method study of reflective essays on the topic of primary school students' awareness of English grammatical forms in online communication in English as a foreign language (EFL). The reflective essays are written in English by a group of Norwegian preservice primary school teachers. This study is informed by the following contentions. First, pre-service primary school teachers need to possess "skills required to facilitate their students' participation and interaction in online contexts" (Satar \& Akcan, 2018, p. 157). Second, pre-service primary school teachers and their future EFL students alike need to ensure that their language is grammatically correct when they write online, in particular, on social Internet media (Godwin-Jones, 2018, p. 1). As evident from these contentions, one of the facets of primary school students' online writing involves their awareness of grammatical forms associated with the use of the English language. However, the current state-of-the-art research does not seem to provide an exhaustive account of the primary school students' grammatical correctness when they write online. Similary, there is insufficient research in the field of EFL/ESL studies that speficifically addresses pre-service primary school teachers' beliefs concerning primary school students' grammatical accuracy in online communication.

Arguably, the present study is relevant, since the use of the Internet, computer mediated communication (CMC), and digital competencies by primary and secondary school students is stipulated by law in Norway (Kelentrić, Helland \& Arstorp, 2017). Digital competency is defined as the confident, critical, and creative use of information and communications technology (ICT) to achieve a variety of goals related to learning, leisure, participation in society, and work (Ferrari, 2012). The specific attention to digital competencies involving $\mathrm{CMC}$ and the use of the Internet has eventuated in wake of The Knowledge Promotion Reform (also known as the $L K 06$ ) that focuses upon reading, mathematics, and English in primary and secondary educational establishments, respectively (Bakken \& Lund, 2018; Knain \& Ødegaard, 2018, p. 16). It should be noted that the Norwegian Ministry for Education and Research emphasises the role of the teachers' digital competencies during their initial teacher education, in continuing professional education and development, and during their teaching career (Kelentrić, Helland, \& Arstorp, 2017).

ELIA 18, 2018, pp. 183-212～DOI: http://dx.doi.org/10.12795/elia.2018.i18.08 
In Norway, "digital skills are defined as an essential proficiency in the national curricular plans" (Langset, Jacobsen, \& Haugsbakken, 2018, p. 25). The institutionalised requirement for digital competencies on the part of the Norwegian Ministry for Education and Research, coupled with a ubiquitous presence of the Internet and CMC in Norwegian primary school landscape, begs the question whether or not EFL students at Norwegian primary schools are aware of grammatical forms in their online communication in the English language. The present article addresses this question by means of an empirical study that is aimed at examining preservice primary school teachers' reflective essays concerning primary school students' awareness of English grammatical forms in their online communication. In total, 10 pre-service primary school teachers (further referred to as 'participants') have been instructed to write a reflective essay on the primary school students' awareness of English grammar in online communication. The participants' reflective essays have been juxtaposed with the essays written by a group of controls comprised of $10 \mathrm{EFL}$ university students, who are not future primary school teachers.

The novelty of this study involves the investigation of primary school students' awareness of grammatical forms in online communication seen through the lenses of future primary school teachers. On the theoretical level, the study further described in this article is embedded into the following notions i) reflective EFL pre-service primary school teachers and their reflective discursive practices and ii) EFL learners' awareness of EFL grammatical forms in their online communication in English. These notions will be outlined in the introductory part. Thereafter, I will present the study of the participants' reflective essays concerning primary school students' awareness of EFL grammatical forms in online communication in English. The study will be concluded with linguo-didactic implications relevant to EFL teaching and learning at Norwegian primary schools.

\subsection{The Notion of a Reflective Pre-Service Primary School Teacher}

Currently, reflective practices receive special attention in EFL/ESL teacher education and research (Atay, 2005; Baecher, 2012; Barcelos \& RuohotieLyhty, 2018; Farrell, 2006; Malmir \& Mohammadi, 2018; Moradkhani, Raygan, \& Moein, 2017; Myles, Cheng, \& Wang, 2006). Taking previous research literature into account, the theoretical tenets of the present study

ELIA 18, 2018, pp. 183-212～DOI: http://dx.doi.org/10.12795/elia.2018.i18.08 
are based upon the notion of a reflective EFL teacher, in particular, a preservice primary school teacher. The notion of a reflective teacher in EFL contexts has been amply elucidated in applied linguistics and EFL/ESL studies (Alter, Hays, \& O'Hara, 2009; Basturkmen, Loewen, \& Ellis, 2004; Chan, 2008; Farrell, 2006; Kember et al., 2008).

Whilst the present article does not aim at providing an exhaustive metaanalysis of the current state-of-the-art research involving reflective practices by pre-service primary school teachers (see Farrell (2006) for a systematic account of pre-service teachers' reflective practices), it is, nevertheless, feasible to suggest that reflections constitute an important variable in the teacher's identity, teacher's beliefs, classroom practices in general, and EFL classroom practices in particular (Borg, 2001; Chan, 2008; Dora To et al., 2011). As indicated by Liou (2001, p. 197), reflection in EFL teacher education facilitates positive changes in teachers' awareness concerning classroom situations, and understanding of teaching-related variables. Similar contention is expressed by Lin and the colleagues (2018), who suggest that reflection "can enable teachers to focus their attention on critical incidents with personal meaning to them" (Lin, Rattray, \& Walker-Gleaves, 2018, p. 128).

It is inferred from a seminal work by Kagan (1992) that pre-service teachers' reflections that are expressed either in oral or written forms can be clustered according to a pre-service teacher's i) pre-existing beliefs and images, ii) personal and professional growth during teaching practice at school, and iii) self-image after teaching practice (Kagan, 1992, p. 133). Echoing Kagan (1992), a robust connection between the teacher's beliefs and reflective practices has been noted by Pajares (1992, p. 307), who indicates that

the beliefs teachers hold influence their perceptions judgments, which, in turn, affect their behavior in the classroom (...) understanding the belief structures of teachers and teacher candidates is essential to improving their professional preparation and teaching.

One of the aspects of the teachers' reflective practices involves the teachers' beliefs concerning grammar (Farrell \& Lim, 2005). In this regard, Robertson and her colleagues (2018) indicate that there is a nexus between the teachers' personal beliefs, individual teaching practices, and the preconceived ideologies related to the actual grammar teaching in an EFL

ELIA 18, 2018, pp. 183-212ＤOI: http://dx.doi.org/10.12795/elia.2018.i18.08 
classroom (Robertson et al., 2018, p. 76). This observation is further supported by Burgess and Etherington (2002), who argue that teachers' reflections on how they teach grammar in EFL settings are suggestive of a disparity between students and teachers in terms of the awareness and importance of grammatical forms (Burgess \& Etherington, 2002, p. 434). It should be noted, however, that whilst there are differences between teachers' and students' reflections on EFL grammar, "teachers may take learner's wishes and preferences into account in their decision making around grammar teaching" (Burgess \& Etherington, 2002, p. 435). The study further presented in this article builds upon the afore-mentioned reflections associated with EFL learners' awareness of grammatical forms in their online communication in English.

\subsection{The Notion of EFL Learners' Awareness of Grammatical Forms in Online Communication in English}

The focus on form in EFL classroom received substantial attention in 1990s, when online communication in English by means of the Internet was less common (Long, 1991; Spada, 1997). According to Long (1991), the focus on form in EFL contexts involves the leaners' attention to form in the sense that they notice and become aware of such linguistic features as, in particular, grammar, and the use of correct grammatical forms in discourse (Basturkmen, Loewen, \& Ellis, 2004, p. 244). In contrast to Long (1991), Spada (1997) proposes to distinguish a focus on form on the one hand and form-focused instruction on the other hand. According to Spada (1997, p. 73), the latter involves "any pedagogical effort which is used to draw the learners' attention to language form either implicitly or explicitly." In those teaching situations, when the learners' attention to the form is drawn explicitly, the teacher preselects a form for attention (Basturkmen, Loewen, \& Ellis, 2004). In the implicit teaching mode, the focus on form "arises naturally out of the performance of a communicative task with no pretargeted language forms" (Basturkmen, Loewen, \& Ellis, 2004, p. 244).

Currently, there appears to be a renewed interest associated with EFL learners' awareness of the grammatical forms in computer-mediated settings that involve online communication (Huang, 2016; Karimi, 2014). This new body of research is informed by an increased use of social networking "that reaches every age demographic" (Eisenchlas, 2012, p. 335), involving, amongst others, primary school EFL learners. As

ELIA 18, 2018, pp. 183-212ＤOI: http://dx.doi.org/10.12795/elia.2018.i18.08 
indicated by Karimi (2014, p. 1), the integration of the Internet into an EFL classroom provides unprecedented opportunities for EFL teachers and learners alike. Presumably, these educational opportunities afforded by the Internet are present both in and outside of primary and secondary schools (Kimber \& Wyatt-Smith, 2010). Extending this contention further, it can be argued that an increased and engaged use of CMC by EFL learners is regarded as textual practices that are acquired through socialisation both in and out of school (Lam, 2004, p. 44). A critical question to be elucidated is whether or not EFL students pay attention to grammatical forms in their $\mathrm{CMC}$ that takes place in and outside of their respective EFL classrooms.

Previous research (Karimi, 2014; Singhal, 1998) does not seem to be unanimous in providing answers to the afore-mentioned question. For instance, Singhal (1998) notes that CMC and the use of the Internet play a facilitative role in the EFL students' language acquisition, inclusive of grammar and vocabulary. However, Kessler (2009) indicates that EFL learners tend to focus exclusively on content without paying attention to grammar. Findings similar to those of Kessler (2009) are reported in Huang (2016), who notes that there is a tendency amongst EFL students in Taiwan to de-emphasise grammatical accuracy in their online communication in English. Specifically, Huang (2016) posits that the lack of attention to grammatical forms is associated with an increase in the students' usage of spoken forms of English in their online writing.

In the light of findings reported by Kessler (2009), and Huang (2016), respectively, it can be argued that there is no straightforward correlation between the use of the Internet and $\mathrm{CMC}$ and progress in terms of the use of correct grammatical forms by EFL learners in their online communication. Moreover, Karimi (2014) suggests that those EFL learners who enjoy an advanced level of the Internet use, have scored lower on EFL grammar tests, whilst beginner EFL learners appear to be more aware of grammatical forms when they write online in English (Karimi, 2014). It is inferred from Karimi's findings that the learners' nascent stage of the Internet use and their less sophisticated beliefs concerning their writing on the Internet use are associated with more substantial gains in their academic achievement in hypermedia contexts. Given the inconclusiveness of previous research that involves EFL learners' awareness of grammatical form in online communication, there are open questions referring to preservice primary school teachers' reflection on EFL students' awareness of

ELIA 18, 2018, pp. 183-212～DOI: http://dx.doi.org/10.12795/elia.2018.118.08 
grammatical forms in English in their online communication. These questions are addressed in the study further described in this article.

\section{The Present Study}

The present study was contextualised within a university course on EFL didactics that was open to pre-service primary school teachers and those students, who took a stand-alone year course in English at a large university in Western Norway. The course duration was one academic year (two semesters). It was designed to provide an overview of different didactic approaches to EFL teaching methods and principles of EFL teaching and learning in primary schools in Norway.

The students who attended the course were expected to take part in classroom discussions and submit two argumentative essays in EFL didactics at the end of each semester (four essays in total). Additionally, the course involved short reflective assignments to be written throughout two semesters. The course was based upon the book English Teaching Strategies by Drew and Sørheim (2016) that consisted of such topics as "Assessment and the European Language Portfolio", "ICT and Didactics", "Integrating Oral and Written Language", etc.

Since one of the topics in the course book was focused upon the use of the Internet and CMC in EFL settings, there was a classroom discussion about online communication in English by primary and middle school students in the Norwegian school system. Specifically, the discussion addressed the issue whether or not primary school students would be aware of the English grammar and grammatical forms when they communicated online in English. That classroom discussion served as an impetus for the present study. In the study, the research design involved a questionnaire and written reflections in the form of short essays on the topic of primary school students' awareness of EFL grammatical forms in their online communication in English.

\subsection{The Hypothesis and Specific Research Aims}

The hypothesis of the study was based upon an assumption that the participants' essays on the topic "Do EFL Learners at Primary Schools Pay

ELIA 18, 2018, pp. 183-212ＤOI: http://dx.doi.org/10.12795/elia.2018.i18.08 
Attention to English Grammar in Their Online Communication?" would be qualitatively different from the essays written by the controls. Specifically, it was assumed in the hypothesis that the participants would frame their essays on the topic in a qualitatively different manner from the controls. The hypothesis factored in the participants' obligatory periods of teaching practice at primary schools, where they had access to realistic conditions of EFL teaching and learning, inclusive of the use of the Internet and CMC by primary school students. Hence, the specific research aims were formulated as followed: i) to identify how the participants frame their reflective essays involving primary school students' awareness of EFL grammatical forms in online communication; ii) to identify how the controls frame their reflective essays on the same topic; and iii) to juxtapose the participants' framing with that of the controls.

\subsection{Participants}

10 participants ( 8 females and 2 males) were matched with 10 controls ( 8 females and 2 males), who were enrolled in the identical EFL course at a large university in Western Norway. The participants' mean age was 24 y.o. (standard deviation $=9$ ) and the controls' mean age was 26 y.o. (standard deviation $=6,7)$. Since the course in EFL Didactics was comprised of 27 students in total (10 participants and 17 non-teacher students), it was possible to match the participants in terms of the gender and age demographics (i.e., the control group was selected on the criteria of the closest age to that of the participants; in terms of gender, 8 females participants were matched with 8 female controls, and 2 male participants were matched with 2 male controls). Three participants indicated that they were working part-time as primary school teachers and one participant was employed on a temporary basis as a substitute teacher. All the participants reported several teaching practice sessions at a range of primary schools in Western Norway. None of the controls indicated that they worked as a teacher or a substitute teacher. The control group never had teaching practice sessions at primary schools.

There were no native speakers of English among the participants and the controls. Norwegian was the first language (L1) for all the participants and all the controls. To ensure confidentiality, the real names of the participants were coded as P1, P2, ... P10 (i.e., the Participant and the

ELIA 18, 2018, pp. 183-212～DOI: http://dx.doi.org/10.12795/elia.2018.118.08 
number). The identical procedure was applied to the controls, whose real names were coded as $\mathrm{C} 1, \mathrm{C} 2, \ldots \mathrm{C} 10$, respectively. The participants and the controls signed the consent form allowing the author of the present article to use their reflective essays and questionnaires for scientific purposes.

\subsection{Procedure}

The procedure involved the following steps: First, the participants and the controls were instructed to fill in a questionnaire pertaining to their sociolinguistic background and the use of online social media (see Appendix 1). Second, the participants and the controls were asked to write three short reflective essays of approximately 300 words each on the topics "Do EFL Learners at Primary School Pay Attention to English Grammar and Spelling in Their Online Communication?", "Would I Encourage my Students to Communicate Online in English?", and "Do I Pay Attention to Grammar and Spelling in My Online Communication in English?". The participants and the controls were given one week to write their reflective essays, which they sent via e-mail to the author of the article. Once all the essays were received by the author, the participants' essays were collapsed into three files in accordance with the titles of the essays and processed in the computer program WordSmith (Scott, 2012). In other words, one file contained all the essays titled "Do EFL Learners at Primary School Pay Attention to English Grammar and Spelling in Their Online Communication?" written by the participants, another file was comprised of the participants' essays "Would I Encourage my Students to Communicate Online in English?", and the third file involved all the essays titled "Do I Pay Attention to Grammar and Spelling in My Online Communication in English?". The identical procedure was applied to the essays written by the controls.

\subsection{The Corpus}

The corpus of the study involved the participants' and controls' essays (i.e., three essays written by each participant and the respective control), thus making it 4911 words in total per group of participants, and 5599 words in total per controls. The mean number of words and standard deviations were calculated in the software program Statistical Package for the Social

ELIA 18, 2018, pp. 183-212～DOI: http://dx.doi.org/10.12795/elia.2018.i18.08 
Sciences (SPSS), version 2009. Those descriptive statistics were summarised in Table 1 below.

\begin{tabular}{|c|c|c|c|}
\hline $\mathbf{N}$ & Reflective Essays & Participants & Controls \\
\hline 1 & $\begin{array}{l}\text { "Do EFL Learners at Primary } \\
\text { Schools Pay Attention to } \\
\text { English Grammar in Their } \\
\text { Online Communication?" }\end{array}$ & $\begin{array}{l}r \text { of } \\
\text { STD } \\
\text { mber } \\
20\end{array}$ & $\begin{array}{l}\text { er of } \\
\text { (STD } \\
\text { mber } \\
09\end{array}$ \\
\hline 2 & $\begin{array}{l}\text { "Would I Encourage my } \\
\text { Students to Communicate } \\
\text { Online in English?" }\end{array}$ & $\begin{array}{l}\text { Mean number of } \\
\text { words }=142(\text { STD } \\
=48) \text {, total number } \\
\text { of words }=1465\end{array}$ & $\begin{array}{l}\text { Mean number of } \\
\text { words }=137 \text { (STD } \\
=54) \text {, total number } \\
\text { of words }=1510\end{array}$ \\
\hline 3 & $\begin{array}{l}\text { "Do I Pay Attention to } \\
\text { Grammar/Spelling in My } \\
\text { Online Communication in } \\
\text { English?" }\end{array}$ & $\begin{array}{l}\text { Mean number of } \\
\text { words }=157(\mathrm{STD} \\
=66) \text {, total number } \\
\text { of words }=1726\end{array}$ & $\begin{array}{l}\text { Mean number of } \\
\text { words }=198(\mathrm{STD} \\
=79) \text {, total number } \\
\text { of words }=2180\end{array}$ \\
\hline
\end{tabular}

Explanation of the abbreviations: STD = standard deviation

Table 1. The Descriptive Statistics of the Corpus

\subsection{Methods}

The theoretical premises of the study were based upon the contention that reflective practices could be conducted in different formats (Chien, 2018; Gabriel, 2017). A reflective essay was assumed to be one of those formats, whose discursive space could be analysed qualitatively by means of the framing analysis. It should be noted that framing was deemed to be a valid research methodology that could be applicable to the present corpus. The framing methodology was applied to the corpus in accordance with theoretical premises proposed by Entman (2004, p. 5), who defined framing as "selecting and highlighting some facets of events or issue, and making connections among them so as to promote a particular interpretation, evaluation, and/or solution". Based upon the definition of framing by Entman (2004), the methodology of the qualitative framing analysis in the study involved the methodological procedure developed by Dahl (2015). Following Dahl (2015), the corpus was manually examined for the presence

ELIA 18, 2018, pp. 183-212～DOI: http://dx.doi.org/10.12795/elia.2018.118.08 
of key words, recurrent phrases, stereotyped expressions, and sentences that provided thematically reinforcing clustering. Then, the manual procedure was verified by means of the computer-assisted count of the most frequent words in the corpus executed by software program WordSmith (Scott, 2012). Thereafter, the corpus was manually examined for the presence of appraisal elements associated with attitudes, feelings, and values used to construe attitudes, engagement, and intensity. Those elements were verified by means of the computer-assisted count of the frequently used words associated with attitudes, feelings, and values. Table 2 below illustrated the frequency count in WordSmith (Scott, 2012) that was identified in the participants' and controls' essays 'Do EFL Learners at Primary Schools Pay Attention to English Grammar in Their Online Communication?"

\section{Most Frequent Words in Participants' Essays}

100 Most Frequent Words in Controls' Essays
English $43(4,4 \%)$, grammar 38 $(3,9 \%)$, I $30(3,1 \%)$, online 27 $(2,8 \%)$, language $24(2,4 \%)$, use 22 $(2,2 \%)$, attention $21(2,1 \%)$, think 18 $(1,8 \%)$, do $17(1,7 \%)$, children $17(1,7 \%)$, pay $15(1,5 \%)$, students $12(1,2 \%)$, you $10(1 \%)$, believe $9 \quad(0,9 \%)$, secondary 8 $(0,8 \%)$, rules $7(0,7 \%)$, them 7 $(0,7 \%)$, write $7(0,7 \%)$, school 7 $(0,7 \%)$, much $6(0,6 \%)$, primary $(0,6 \%)$, spelling $6(0,6 \%)$, learners 6 $(0,6 \%)$, way $5(0,5 \%)$, people 5 $(0,5 \%)$, knowledge $(0,5 \%)$, lot 5 $(0,5 \%)$, using $5(0,5 \%)$, enough 5 $(0,5 \%)$, media $5(0,5 \%)$, even 5 $(0,5 \%)$, get $5(0,5 \%)$, however 5 $(0,5 \%)$, communicate $5(0,5 \%)$, likely $5(0,5 \%)$, schools $4(0,4 \%)$, without $4(0,4 \%)$, many $(0,4 \%)$, makes $4(0,4 \%)$, good $4(0,4 \%)$, writing $(0,4 \%)$, communication
I $42(4,2 \%)$, grammar $30(3 \%)$, English 27 (2,7\%), online 22 (2,2\%), school $19(1,9 \%)$, language 15 $(1,5 \%)$, think $15(1,5 \%)$, you 12 $(1,2 \%)$, correct $11(1,1 \%)$, time 11 $(1,1 \%)$, students $10(1 \%)$, primary 10 $(1 \%)$, do $9 \quad(0,9 \%)$, learners 9 $(0,9 \%)$, what $8(0,8 \%)$, important 8 $(0,8 \%)$, very $8(0,8 \%)$, pay $7(0,7 \%)$, care $7(0,7 \%)$, least $7(0,7 \%)$, attention $7(0,7 \%)$, use $7(0,7 \%)$, however $7(0,7 \%)$, writing $6(0,6 \%)$, these $6(0,6 \%)$, write $6(0,6 \%)$, learning $6(0,6 \%)$, EFL $6(0,6 \%)$, how $6(0,6 \%)$, secondary $6(0,6 \%)$, don't $6(0,6 \%)$, older $5(0,5 \%)$, point $5(0,5 \%)$, media $5(0,5 \%)$, need 5 $(0,5 \%)$, my $5(0,5 \%)$, age $5(0,5 \%)$, correctly $5(0,5 \%)$, believe $5(0,5 \%)$, learn $5(0,5 \%)$, like $5(0,5 \%)$, me $5(0,5 \%)$, get $5(0,5 \%)$, being 5 $(0,5 \%)$, student $4 \quad(0,4 \%)$, 
100 Most Frequent Words in Participants' Essays
100 Most Frequent Words in Controls' Essays don't $4(0,4 \%)$, friends $4(0,4 \%)$, my $4(0,4 \%)$, comes $4(0,4 \%)$, EFL 4 $(0,4 \%)$, then $4(0,4 \%)$, different 4 $(0,4 \%)$, Norwegian $3(0,3 \%)$, your 3 $(0,3 \%)$, though $3(0,3 \%)$, important $3(0,3 \%)$, those $3(0,3 \%)$, social 3 $(0,3 \%)$, therefore $3(0,3 \%)$, new 3 $(0,3 \%)$, second $3(0,3 \%)$, thinking 3 $(0,3 \%)$, native $3(, 3 \%)$, mostly 3 $(0,3 \%)$, time $3(0,3 \%)$, day $3(0,3 \%)$, first $3(0,3 \%)$, correct $3(0,3 \%)$, might $3(0,3 \%)$, tongue $3(0,3 \%)$, hard $3(0,3 \%)$, see $3(0,3 \%)$, paying $3(0,3 \%)$, really $3(0,3 \%)$, sentence 3 $(0,3 \%)$, bigger $2(0,2 \%)$, used 2 $(0,2 \%)$, abbreviations $2(0,2 \%)$, sometimes $2(0,2 \%)$, example 2 $(0,2 \%)$, subject $(0,2 \%)$, sentence 2 $(0,2 \%)$, understand $2(0,2 \%)$, start 2 $(0,2 \%)$, world $2(0,2 \%)$, both 2 $(0,2 \%)$, things $2(0,2 \%)$, development $2(0,2 \%)$, games 2 $(0,2 \%)$, every $2(0,2 \%)$, easier 2 $(0,2 \%)$, probably $2(0,2 \%)$, acronyms $2(0,2 \%)$, became $2(0,2 \%)$, eager 2 $(0,2 \%)$, should $2(0,2 \%)$, common 2 $(0,2 \%)$, well $2(0,2 \%)$, need 2 $(0,2 \%)$, story $2(0,2 \%)$, care 2 $(0,2 \%)$, years $2(0,2 \%)$, show 2 $(0,2 \%)$, young $2(0,2 \%)$, whole 2 $(0,2 \%)$ grammatical $4(0,4 \%)$, speculating 4 $(0,4 \%)$, schoolchildren $4(0,4 \%)$, spelling $4(0,4 \%)$, interested 4 $(0,4 \%)$, see $4(0,4 \%)$, try $4(0,4 \%)$, person $4(0,4 \%)$, want $4(0,4 \%)$, social $4(0,4 \%)$, day $4(0,4 \%)$, question $4(0,4 \%)$, likely $4(0,4 \%)$, better $4(0,4 \%)$, second $4(0,4 \%)$, young $4(0,4 \%)$, much $4(0,4 \%)$, seeing $3(0.3 \%)$, communicate 3 $(0,3 \%)$, those $3(0,3 \%)$, checking 3 $(0,3 \%)$, even $3(0,3 \%)$, something 3 $(0,3 \%)$, did $3(0,3 \%)$, example 3 $(0,3 \%)$, Norwegian $3(0,3 \%)$, class 3 $(0,3 \%)$, instance $3(0,3 \%)$, where 3 $(0,3 \%)$, spend $3(0,3 \%)$, anything 3 $(0,3 \%)$, another $3(0,3 \%)$, feel 3 $(0,3 \%)$, probably $3(0,3 \%)$, speak 3 $(0,3 \%)$, far $3(0,3 \%)$, trained 3 $(0,3 \%)$, relationship $3(0,3 \%)$, used $3(0,3 \%)$, personally $3(0,3 \%)$, make $3(0,3 \%)$, activities $3(0,3 \%)$, too 3 $(0,3 \%)$, children $3(0,3 \%)$, countries $3(0,3 \%)$, might $3(0,3 \%)$, really 3 $(0,3 \%)$, schools $2(0,2 \%)$, home 2 $(0,2 \%)$, perhaps $2(0,2 \%)$, Facebook $2(0,2 \%)$, therefore $2(0,2 \%)$, require $2(0,2 \%)$, usage $2(0,2 \%)$, able 2 $(0,2 \%)$, using $2(0,2 \%)$, text 2 $(0,2 \%)$

Table 2. The Most Frequent Words (per 1000 Words) in the Reflective Essay "Do EFL Learners at Primary Schools Pay Attention to English Grammar in Their Online Communication?"

ELIA 18, 2018, pp. 183-212ＤOI: http://dx.doi.org/10.12795/elia.2018.i18.08 
As seen in Table 2, the word frequency data appeared to be different between the groups of participants and controls. In order to graphically visualise the differences in the frequent words between the groups, 10 most frequent words from Table 2 were plotted in Microsoft Excel and presented as Figure 1 below:

Percentage of 10 most frequent words

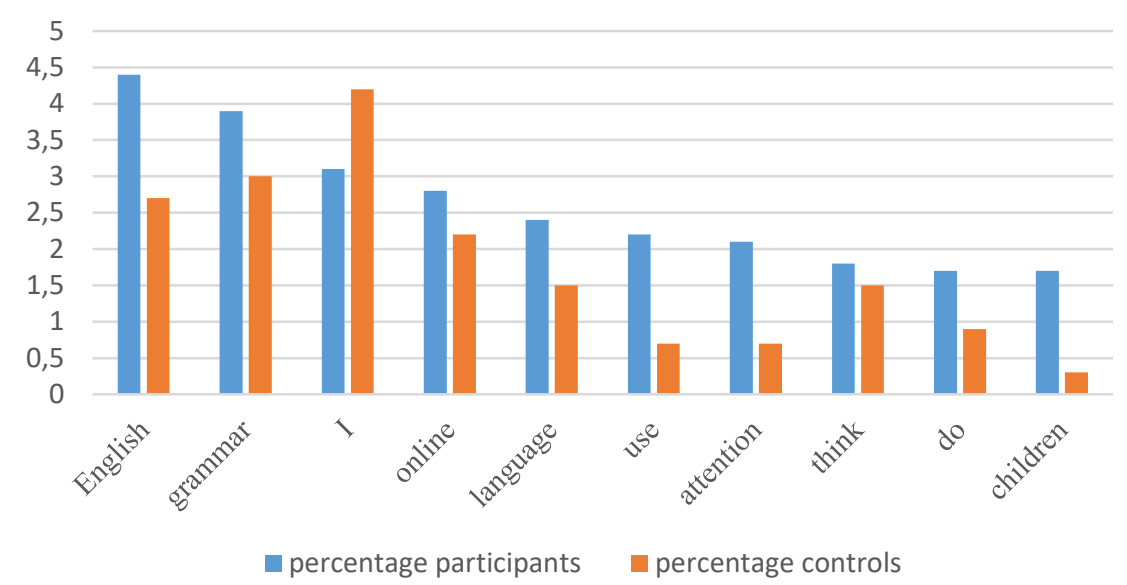

Figure 1. Percentage of 10 Most Frequent Words in the Participants' Essays "Do EFL Learners at Primary Schools Pay Attention to English Grammar in Their Online Communication?" Contrasted with the Control Group

The combination of the manual examination of the corpus with the computer-assisted words frequency count per 1000 words (see examples provided in Table 2) enabled the author of the article to analyse the framing. The labelling in the framing analysis was based upon the presence of the key words and recurrent phrases in the given stretch of discourse. The results of the framing analysis were double-checked by a linguist with a $\mathrm{PhD}$ in discourse studies, who confirmed the labelling used in the framing analysis.

\subsection{Results and Discussion}

The application of the most frequent words count and the manual qualitative analysis of the corpus in accordance with the framing methodology have

ELIA 18, 2018, pp. 183-212～DOI: http://dx.doi.org/10.12795/elia.2018.i18.08 
resulted in the labelling of the frames summarised in Table 3. In this Table, the frames are listed in alphabetical order and the presence of the particular frame in the corpus is marked either by YES or NO.

\begin{tabular}{|c|l|c|c|}
\hline $\mathbf{N}$ & \multicolumn{1}{|c|}{ Frame } & Participants & Controls \\
\hline 1 & Attention to Grammar & YES & NO \\
\hline 2 & Avoidance of Writing & NO & YES \\
\hline 3 & Encouragement & YES & YES \\
\hline 4 & Individual Differences & YES & NO \\
\hline 5 & Informal Language & YES & YES \\
\hline 6 & No Attention to Grammar & YES & YES \\
\hline 7 & Subjective Opinion & YES & YES \\
\hline
\end{tabular}

Table 3. The Framing of the Participants' and Controls' Reflective Essays

As previously mentioned in the subsection 2.1 of this article, the hypothesis in the study is based upon the assumption that the participants' reflective essays would be qualitatively different from the essays written by the controls. Judging from Table 3, the hypothesis is supported by the data analysis. Specifically, the results of the framing analysis summarised in Table 3 point to qualitative differences between the groups of participants and controls, since the distribution of the frames in the corpus differs between them. Notably, the frames "Attention to Grammar", and "Individual Differences" have been identified exclusively in the participants' essays. In contrast to the participants' essays, the frame "Avoidance of Writing" is present only in the reflective essays written by the controls. However, there are common frames in the participants' and the controls' reflective essays, e.g. "Encouragement", "Informal Language", "No Attention to Grammar", and "Subjective Opinion".

It should be emphasised that the specific research aims of this study involve the question of how the participants and their controls frame their reflective essays associated with primary school students' grammatical awareness in online communication in English. In addition to identifying 
the framing, another specific research question seeks to address the differences in framing between the groups of participants and controls. As evident from the findings summarised in Table 3, seven frames in total have been identified in the corpus of the participants' and controls' reflective essays, e.g. "Attention to Grammar", "Avoidance of Writing", "Encouragement", "Individual Differences", "No Attention to Grammar", "Informal Language", and "Subjective Opinion". Given that the frames have been identified in the corpus and, subsequently, juxtaposed between the groups of participants and controls, it can be argued that the specific research aims have been achieved.

Prior to a more detailed analysis of the frames outlined in Table 3, it appears relevant to present and discuss the participants' and controls' questionnaire data associated with their linguistic behaviour on social media. The application of the software program SPSS (2009) to the questionnaire data has yielded the descriptive statistics that are summarised in Table 4 below.

\begin{tabular}{|c|c|c|c|}
\hline $\mathbf{N}$ & Questionnaire Rubric & Participants & Controls \\
\hline 1 & The use of social media & $100 \%$ & $100 \%$ \\
\hline 2 & $\begin{array}{l}\text { Type of social media used } \\
\text { Facebook } \\
\text { Instagram } \\
\text { Twitter } \\
\text { Snapchat } \\
\text { WhatsApp }\end{array}$ & $\begin{array}{l}100 \% \\
80 \% \\
- \\
40 \% \\
10 \%\end{array}$ & $\begin{array}{l}100 \% \\
100 \% \\
10 \% \\
30 \% \\
-\end{array}$ \\
\hline 3 & $\begin{array}{l}\text { Frequency of writing on social media in } \\
\text { Norwegian } \\
\text { Often } \\
\text { Sometimes } \\
\text { Never }\end{array}$ & $\begin{array}{l}50 \% \\
40 \% \\
10 \%\end{array}$ & $\begin{array}{l}60 \% \\
20 \% \\
20 \%\end{array}$ \\
\hline 4 & $\begin{array}{l}\text { Frequency of writing on social media in } \\
\text { English } \\
\text { Often } \\
\text { Sometimes } \\
\text { Never }\end{array}$ & $\begin{array}{l}30 \% \\
50 \% \\
20 \%\end{array}$ & $\begin{array}{l}70 \% \\
10 \% \\
20 \%\end{array}$ \\
\hline
\end{tabular}

ELIA 18, 2018, pp. 183-212～DOI: http://dx.doi.org/10.12795/elia.2018.i18.08 


\begin{tabular}{|c|c|c|c|}
\hline $\mathbf{N}$ & Questionnaire Rubric & Participants & Controls \\
\hline 5 & $\begin{array}{l}\text { Attention to grammar and spelling when } \\
\text { writing on social media in Norwegian } \\
\text { Yes } \\
\text { No }\end{array}$ & $\begin{array}{l}90 \% \\
10 \%\end{array}$ & $\begin{array}{l}60 \% \\
40 \%\end{array}$ \\
\hline 6 & $\begin{array}{l}\text { Attention to grammar and spelling when } \\
\text { writing on social media in English } \\
\text { Yes } \\
\text { No }\end{array}$ & $\begin{array}{l}90 \% \\
10 \%\end{array}$ & $\begin{array}{l}70 \% \\
30 \%\end{array}$ \\
\hline 7 & $\begin{array}{l}\text { Problems with grammar and spelling } \\
\text { when writing on social media in } \\
\text { Norwegian } \\
\text { Yes } \\
\text { No }\end{array}$ & $\begin{array}{l}10 \% \\
90 \%\end{array}$ & $\overline{100 \%}$ \\
\hline 8 & $\begin{array}{l}\text { Problems with grammar and spelling } \\
\text { when writing on social media in English } \\
\text { Yes } \\
\text { No }\end{array}$ & $\begin{array}{l}60 \% \\
40 \%\end{array}$ & $\begin{array}{l}10 \% \\
90 \%\end{array}$ \\
\hline
\end{tabular}

Table 4. The Participants' and Controls' Linguistic Behaviour on Social Media

As seen in Table 4, all the participants and all the controls use online social media. Notably, $50 \%$ of the participants and $60 \%$ of the controls often write online in Norwegian. However, $30 \%$ of the participants and $70 \%$ of the controls indicate that they often write in English on social platforms. It is evident from Table 4 that the participants tend to pay more attention to grammar, when they write in Norwegian in online $(90 \%)$, compared to the controls (60\%). Whilst $90 \%$ of the participants and $70 \%$ of the controls pay attention to English grammar when they write online, $60 \%$ of the participants report that they experience problems with grammar and spelling when they write on social media platforms in English. These findings are illustrated by Figure 2 below:

ELIA 18, 2018, pp. 183-212ＤOI: http://dx.doi.org/10.12795/elia.2018.i18.08 


\section{Percentage}

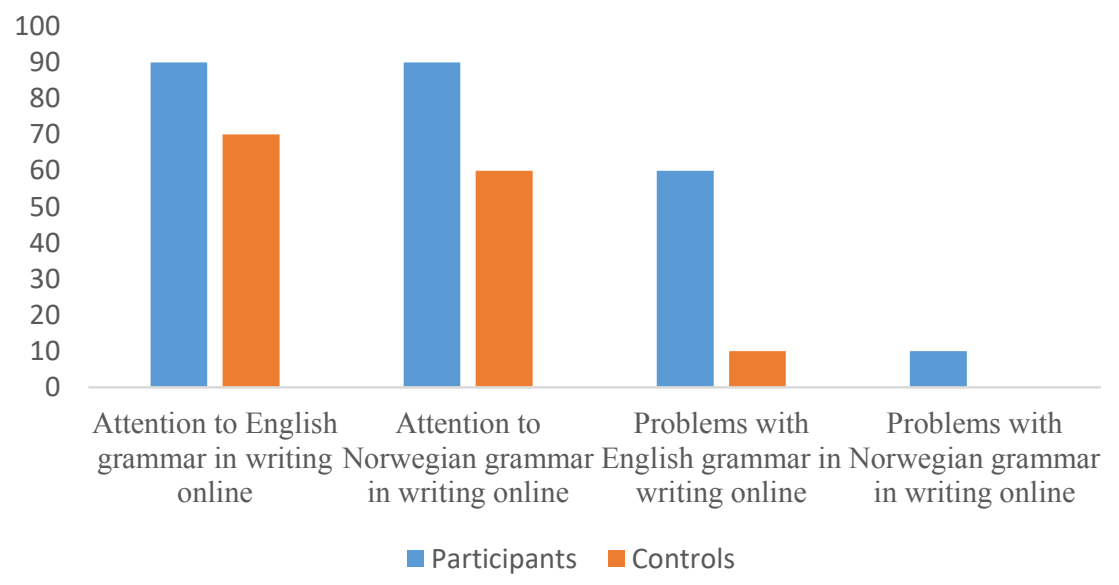

Figure 2. Percentage of Participants and Controls Who Pay Attention to English Grammar and Experience Problems with English Grammar Online

It is evident from Figure 2 that the participants appear to be more attentive to grammar and grammatical forms when they write online in English and in Norwegian, respectively. The participants' awareness of the grammatical forms in English in online writing is coupled with a higher level of self-criticism when they self-assess their problems with English grammar in online writing. Presumably, self-criticism is evident from those $60 \%$ of the participants, who report problems with EFL grammar and spelling (see Figure 2). This finding lends indirect support to previous research conducted by Reves and Medgyes (1994), who posit that EFL teachers tend to be critical in their self-assessment of EFL skills, including grammar. Interestingly, critical self-assessment of EFL grammar skills is absent in the control group, since $90 \%$ of the controls indicate that they do not have problems with EFL grammar and spelling when they write in English on social media platforms (see Figure 2 and Table 4).

Whilst $90 \%$ of the participants write in the questionnaire that they pay attention to grammar in their online communication in English, it is inferred from the reflective essays "Do I Pay Attention to Grammar/ Spelling in My Online Communication in English?" that all the participants

ELIA 18, 2018, pp. 183-212ＤOI: http://dx.doi.org/10.12795/elia.2018.i18.08 
(i.e., $100 \%$ ) pay attention to English grammar when they write online. This finding is in agreement with the contention formulated by Godwin-Jones (2018), who argues that pre-service primary school teachers should be aware of their correct grammar in online writing, since it is very likely that if primary school teachers write grammatically correct in English on social media, then they would be more sensitive and aware of their EFL students' correct grammatical writing in online contexts. This observation is in concert with Robertson and the colleagues (2018), who posit that the teacher's personal practices, for instance grammatical correctness in online contexts, are related to the actual teaching of grammar in an EFL classroom (Robertson et al., 2018, p. 76).

Given that all the participants and their controls report online use of social media in English (see Table 4), it is, perhaps, not surprising that both the participant and control groups structure their essays "Would I Encourage my Students to Communicate Online in English?" by means of the frame "Encouragement". The presence of this frame is suggestive of the positive view of online communication in English by primary school students. Indirectly, this finding supports previous research (Singhal, 1998) that indicates that $\mathrm{CMC}$ and online communication on the Internet have a positive influence upon the acquisition of grammar and vocabulary by EFL students. Whilst only one frame ("Encouragement") is present in the essays "Would I Encourage my Students to Communicate Online in English?", the framing analysis of the reflective essays "Do EFL Learners at Primary Schools Pay Attention to English Grammar in Their Online Communication?" has yielded a variety of qualitatively different frames. Further, I will present and discuss some of the typical examples of the frames summarised in Table 3.

As evident from Table 3, the participants' framing of primary school students' awareness of EFL grammatical forms in online communication in English is marked by the frame "Attention to Grammar". This frame has been identified in the reflective essays written by 7 participants. It should be reiterated that all the participants, unlike the control group comprised of the non-teacher students, have had several teaching practice sessions at Norwegian primary schools. Arguably, the participants' direct exposure to the primary school students' CMC and online practices has mapped onto their belief that primary school students are aware of English grammar in their online communication. This belief is reflected in the frame "Attention to Grammar". It is further illustrated by excerpt (1) below:

ELIA 18, 2018, pp. 183-212～DOI: http://dx.doi.org/10.12795/elia.2018.i18.08 
(1) Today everyone uses social media even children as young as six years old. I think that even though EFL learners at primary and secondary schools are quite young and still learning English they do pay attention to English grammar online, when they use social media. That is because they learn about correct English grammar and spelling at school almost every day. (Participant P 4)

Interestingly, Participant P 4 reflects upon the reasons associated with the primary school students' awareness of English grammar in online communication. According to the Participant, the primary school students' awareness of English grammar stems from formal schooling, playing online games that "require that they talk/write in English", extensive travelling, and using English with those "students in their class or in the neighbourhood who are new to the country and do not speak Norwegian yet" (Participant P 4).

However, 3 out of 7 participants frame their reflective essays by the frame "No Attention to Grammar", which is in contrast to the previously discussed frame "Attention to Grammar". The frame "No Attention to Grammar" is seen in excerpt (2):

(2) In my opinion, students at primary schools do not pay much attention to grammar. I think for the majority of them, English grammar is very hard. I think that they will do their best in class, but when school is over and they use English online at home, they will not pay attention to grammar any more. (Participant P 9)

It should be noted, however, that whilst Participant P 9 frames primary school students' grammar awareness negatively, e.g. “... students at primary schools do not pay much attention to grammar", this Participant argues that "when those students go to secondary school, the situation will change. Their English will become better and they will find it easier to write and speak English and then they will pay attention to grammar" (Participant P9).

As seen in Table 3 and in excerpts (1) and (2), the participants' reflections are characterised by two contrasting frames, "Attention to Grammar" and "No Attention to Grammar". However, judging from the participants' reflective essays it can be argued that the contrast is gradual rather than abrupt. For instance, Participant P 9 indicates that primary 
school students do not pay attention to English grammar, but then the Participant posits that those students who do not pay attention to EFL grammar in primary school will be aware of it in secondary school. Presumably, the frames "Attention to Grammar" and "No Attention to Grammar" that have been identified in the participants' essays construe a polyphonic discursive space. The polyphony is composed of two contrastive frames, with the contrast being gradual. The polyphony of these two frames can be explained by a contention that pre-service teachers' personal and professional experiences are subject to change during and after teaching practice at school (Kagan, 1992). Presumably, the participants have experienced a variety of teaching situations during their school practice that mapped onto the contrastive frames "Attention to Grammar" and "No Attention to Grammar".

Unlike the participants, the control group has never been to a teaching practice session. The absence of previous exposure to teaching experience and, presumably, limited exposure to primary schools in their adult lives have resulted in the frame "No Attention to Grammar". To reiterate, the frame "Attention to Grammar" is absent in the reflective essays written by the control group. Judging from the data, the controls are unanimous in the framing of their reflective essays as the frame "No Attention to Grammar". This frame can be illustrated by the following quotes: i) "one of my classmates asked her brother the same question and he is in primary school. He said that he does not care about English grammar at all online" (Control C 7); ii) "I think that students in primary school do not consciously consider the more technical aspects of English grammar when online" (Control C 2). These quotes are typical of the reflective essays written by the control group. This finding provides indirect support to previous research by Kessler (2009), who argues that EFL learners prioritise content without paying attention to grammar. Additionally, this finding is in concert with Huang (2016), who reports the tendency to de-emphasise grammatical accuracy in online communication by EFL learners.

Another typical feature that is found in the reflective essays written by the controls is the frame "Avoidance of Writing". As seen in Table 3, this frame is present in the reflective essays written by the controls, and absent in the participants' essays. The frame "Avoidance of Writing" is illustrated by excerpt (3):

ELIA 18, 2018, pp. 183-212ＤOI: http://dx.doi.org/10.12795/elia.2018.i18.08 
(3) ... they have problems with the spelling and grammar. In the society today there is an constant need to be perfect in everything you do, whether it's football, school, clothes or being popular. It's enormous pressure to have when you are just a child. I think they try to avoid writing in English online because they are scared to misspell something or write something the wrong way, only to hear about it at school the next day. (Control C 5)

It follows from excerpt (3) that Control C 5 frames primary school students' online writing as the absence thereof due to avoidance, e.g. "... they try to avoid writing in English online" (Control C 5). The avoidance of writing online is explained by i) social pressure and perfectionism (see excerpt 3 ), ii) potential bullying (referred to in the essay by Control C 2 ), and iii) practical considerations when primary school students refuse to write on the grounds that English is not important and practical to them (mentioned by Control C 8).

Similarly to the frame "Avoidance of Writing" that is present only in the essays written by the controls, the frame "Individual Differences" is not equally distributed in the corpus. The frame "Individual Differences" appears to be present in the participants' essays, whilst their respective controls do not seem to mention the notion of individual differences associated with online writing by primary school students. The participants appear to relate the frame "Individual Differences" to EFL acquisition and grammar awareness on the part of the primary school students, as seen in excerpt (4):

(4) I think it's a difficult subject to reflect on because everybody is different. I think that some do care about English grammar online, and that some really don't pay too much attention when it comes to grammar. I also think that the more knowledge you have about grammar, the more you pay attention to it. (Participant P 6)

It should be observed that this framing would be expected in the participants' reflective essays, since they have had their teaching practice sessions at school. Presumably, school practice would provide the participants with realistic input in terms of the variety of the cohort of primary school students.

The frame "Informal Language" is equally distributed in the reflective essays written by the participants and controls, respectively. The 
presence of this frame offers indirect support to previous findings reported by Huang (2016), who indicates that EFL students' insufficient attention to grammatical forms is associated with an increase in the use of informal forms of the English language in online writing. The frame "Informal Language" is further illustrated by excerpt (5):

(5) Do students pay attention to their grammar online? That is a multilayered question I believe. When online interactions became more common, the need for abbreviations and shortcuts became more common as well. People wanted to speed things up by creating these and they've even found a way into our spoken tongue as well. This is a development that shows that students actually are paying attention to language, and therefore grammar, in a way. However, when the time comes for the students to produce something, they write the words down the way they hear it. (Participant P 2)

It is evident from excerpt (5) that Participant P 2, a future primary school teacher, argues that primary school students are likely to write in English "the way they hear it" (Participant P 2), i.e., primary school students' online writing in English would be reflective of their spoken English. The same argument is shared by the controls, who suggest that primary school students would use colloquial forms of English, abbreviations, and other informal forms of writing.

Notably, it is observed in the data that the participants and controls express their opinions and beliefs about primary school students' awareness of EFL grammatical forms subjectively. Each essay on the topic "Do EFL Learners at Primary Schools Pay Attention to English Grammar in Their Online Communication?" contains such hedges, as "I think", "I believe", "in my opinion", etc. that are present in the frame "Subjective Opinion". In other words, the participants and controls indicate that their reflections on the primary school students' awareness of EFL grammatical forms in online communication is a subjective matter, expressed by an opinion, a belief, or a presupposition. The frame "Subjective Opinion" is embedded into other frames enumerated in Table 3. For instance, the frame "Subjective Opinion" is present in the frames i) "Attention to Grammar", e.g. "I think that even though EFL learners at primary and secondary schools are quite young and still learning English they do pay attention to English grammar online..." (Participant P 4); ii) "Avoidance of Writing", e.g. "I think they try to avoid writing in English online because they are scared to misspell

ELIA 18, 2018, pp. 183-212～DOI: http://dx.doi.org/10.12795/elia.2018.118.08 
something or wright something the wrong way ..." (Control C 5); iii) "Individual Differences", e.g. "I think it's a difficult subject to reflect on because everybody is different. I think that some do care about English grammar online, and that some really don't pay too much attention when it comes to grammar" (Participant P 6); iv) "No Attention to Grammar", e.g. "In my opinion, students at primary schools do not pay much attention to grammar." (Participant P 9); and v) "Informal Language", e.g. "Do students pay attention to their grammar online? That is a multi-layered question I believe." (Participant P 2).

\section{Conclusions and Pedagogical Implications}

This article presents a mixed-method study that involves reflective essays on whether or not primary school students are aware of EFL grammatical forms when they communicate online in English. The aims of the study are to elucidate how the reflective essays are framed and to juxtapose them in order to reveal possible differences in the framing between the group of participants and their respective controls. The research methodology in this study involves framing analysis proposed by Entman (2004) and developed by Dahl (2015). The results of the data analysis indicate that the participants' reflective essays are framed by the frames: "Attention to Grammar", "Encouragement", "Individual Differences", "Informal Language", "No Attention to Grammar", and "Subjective Opinion". The controls frame their reflective essays by means of the frames "Avoidance of Writing", "Encouragement", "Informal Language", "No Attention to Grammar", and "Subjective Opinion".

Judging from the findings, the majority of the participants share a contention that primary school students are aware of EFL grammatical forms in their writing online, whilst the controls indicate that primary school students are unaware of EFL grammatical forms in their online written communication. Presumably, this finding will contribute to a better understanding of primary school students' online communication in English. It is also assumed that the present study will provide a baseline for future research involving online communication by primary school students, which is considered an underrepresented area in applied linguistics (Robertson et al., 2018).

ELIA 18, 2018, pp. 183-212ＤOI: http://dx.doi.org/10.12795/elia.2018.i18.08 
Obviously, the present findings should be treated with caution, since the number of participants and controls in the study is limited (total $\mathrm{N}=$ 20). However, even with this small-scale study, it seems possible to offer a number of pedagogical implications that, presumably, would be relevant to EFL teaching and learning in primary schools. First, given the current emphasis on $\mathrm{CMC}$ and digital literacy, it appears pertinent to encourage primary school students to communicate online in English. Second, EFL grammatical forms in online and $\mathrm{CMC}$ communication should be introduced and paid attention to starting from the level of primary school. Third, teacher training programmes should offer suggestions to pre-service primary school teachers on how to facilitate primary school students' online writing in English.

\section{Acknowledgements}

The author of this article wishes to acknowledge 20 students who took part in the study. Their participation is invaluable and highly appreciated. The study was financed by Western Norway University of Applied Sciences, campus Haugesund/Stord.

\section{References}

Alter, F., Hays, T., \& O'Hara, R. (2009). Creative arts teaching and practice: Critical reflections of primary school teachers in Australia. International Journal of Education \& the Arts, 10(9), 9. Accessed on 15 April 2018 at http://www.ijea.org/v10n9/.

Atay, D. (2005). Reflections on the cultural dimension of language teaching. Language and Intercultural Communication, 5(3-4), 222-236.

Baecher, L. (2012). Feedback from the Field: What Novice PreK-12 ESL Teachers Want to Tell TESOL Teacher Educators. TESOL Quarterly, 46(3), 578-588.

Bakken, A. S., \& Lund, R. E. (2018). Why should learners of English read? Norwegian English teachers' notions of EFL reading. Teaching and Teacher Education, 70, 78-87.

ELIA 18, 2018, pp. 183-212ＤOI: http://dx.doi.org/10.12795/elia.2018.i18.08 
Barcelos, A. M. F., \& Ruohotie-Lyhty, M. (2018). Teachers' Emotions and Beliefs in Second Language Teaching: Implications for Teacher Education. In J. de Dios Martínez Agudo (ed.) Emotions in Second Language Teaching (pp. 109-124). Cham, Switzerland: Springer.

Basturkmen, H., Loewen, S., \& Ellis, R. (2004). Teachers' stated beliefs about incidental focus on form and their classroom practices. Applied Linguistics, 25(2), 243-272.

Borg, S. (2001). Self-perception and practice in teaching grammar. ELT Journal, 55(1), 21-29.

Burgess, J., \& Etherington, S. (2002). Focus on grammatical form: explicit or implicit?. System, 30(4), 433-458.

Chan, Y. C. (2008). Elementary school EFL teachers' beliefs and practices of multiple assessments. Reflections on English Language Teaching, 7(1), 3762.

Chien, C. W. (2018). Analysis of design and delivery of critical incident workshops for elementary school English as a foreign language teachers in community of practice. Education 3-13, 46(1), 1-15.

Dahl, T. (2015). Contested science in the media: Linguistic traces of news writers' framing activity. Written Communication, 32(1), 39-65.

Dora To, L. W., Phoebe Chan, Y. L., Lam, Y. K., \& Tsang, S. K. Y. (2011). Reflections on a primary school teacher professional development programme on learning English through process drama. Research in Drama Education: The Journal of Applied Theatre and Performance, 16(4), 517539.

Drew, I., \& Sørheim, B. (2016). English teaching strategies: Methods for English teachers of 10 to 16 year olds. Oslo: Det Norske Samlaget.

Eisenchlas, S. A. (2012). Gendered discursive practices on-line. Journal of Pragmatics, 44(4), 335-345.

Entman, R. M. (2004). Projections of power: Framing news, public opinion, and US foreign policy. University of Chicago Press.

ELIA 18, 2018, pp. 183-212ＤOI: http://dx.doi.org/10.12795/elia.2018.i18.08 
Farrell, T. S. (2006). Reflective practice in action: A case study of a writing teacher's reflections on practice. TESL Canada Journal, 23(2), 77-90.

Farrell, T. S., \& Lim, P. C. P. (2005). Conceptions of Grammar Teaching: A Case Study of Teachers' Beliefs and Classroom Practices. TESL-EJ, 9(2), 1-13.

Ferrari, A. (2012). Digital Competence in Practice. European Commission Joint Research Centre. Institute for Prospective Technological Studies. Spain: Seville. Accessed on 14 April 2018 at http://ftp.jrc.es/EURdoc/JRC68116. pdf

Gabriel, R. (2017). Rubrics and Reflection: A Discursive Analysis of Observation Debrief Conversations between Novice Teach for America Teachers and Mentors. Action in Teacher Education, 39(1), 85-102.

Godwin-Jones, R. (2018). Second language writing online: An update. Language Learning \& Technology, 22(1), 1-15. https://dx.doi.org/10125/44574

Huang, L. J. (2016). Discourse Organization and Features of Email Writing Among EFL Students in Taiwan. In Y.-sh. Chen, D.-H. V. Rau and G. Rau (eds.) Email Discourse Among Chinese Using English as a Lingua Franca (pp. 37-59). Singapore: Springer.

Kagan, D. M. (1992). Professional growth among preservice and beginning teachers. Review of educational research, 62(2), 129-169.

Karimi, M. N. (2014). EFL students' grammar achievement in a hypermedia context: Exploring the role of Internet-specific personal epistemology. System, 42, 1-11.

Kelentrić, M., Helland, K., \& Arstorp, A.-T. (2017). Professional Digital Competence Framework for Teachers. Accessed on 15 April 2018 at https:// www.udir.no/globalassets/filer/in-english/pfdk_framework_en_low2.pdf

Kember, D., McKay, J., Sinclair, K., \& Wong, F. K. Y. (2008). A four-category scheme for coding and assessing the level of reflection in written work. Assessment \& Evaluation in Higher Education, 33(4), 369-379.

Kessler, G. (2009). Student-initiated attention to form in wiki-based collaborative writing. Language Learning \& Technology, 13(1), 79-95.

ELIA 18, 2018, pp. 183-212ＤOI: http://dx.doi.org/10.12795/elia.2018.i18.08 
Kimber, K., \& Wyatt-Smith, C. (2010). Secondary students' online use and creation of knowledge: Refocusing priorities for quality assessment and learning. Australasian journal of educational technology, 26(5).

Knain, E., \& Ødegaard, M. (2018). The Implementation of Scientific Literacy as Basic Skills in Norway After the School Reform of 2006. In K.-S. Tang and K. Danielsson (eds.) Global Developments in Literacy Research for Science Education (pp. 15-28). Cham, Switzerland: Springer.

Lam, W. S. E. (2004). Second language socialization in a bilingual chat room: Global and local considerations. Language Learning \& Technology, 8(3), 44-65.

Langset, I. D., Jacobsen, D. Y., \& Haugsbakken, H. (2018). Digital professional development: towards a collaborative learning approach for taking higher education into the digitalized age. Nordic Journal of Digital Literacy, 13(01), 24-39.

Lin, S. W., Rattray, J., \& Walker-Gleaves, C. (2018). Reflections on my experience of developing and implementing a metalearning program for an EFL elective course in a Taiwanese secondary school. Thinking Skills and Creativity, 27, 123-130.

Liou, H. C. (2001). Reflective practice in a pre-service teacher education program for high school English teachers in Taiwan, ROC. System, 29(2), 197-208.

Long, M. H. (1991). Focus on form: A design feature in language teaching methodology. Foreign Language Research in Cross-Cultural Perspective, 2(1), 39-52.

Malmir, A., \& Mohammadi, P. (2018). Teachers' Reflective Teaching and SelfEfficacy as Predicators of their Professional Success: A Case of Iranian EFL Teachers. Research in English language pedagogy, 6(1), 117-138.

Moradkhani, S., Raygan, A., \& Moein, M. S. (2017). Iranian EFL teachers' reflective practices and self-efficacy: Exploring possible relationships. System, 65, 1-14.

Myles, J., Cheng, L., \& Wang, H. (2006). Teaching in elementary school: Perceptions of foreign-trained teacher candidates on their teaching practicum. Teaching and Teacher education, 22(2), 233-245.

ELIA 18, 2018, pp. 183-212ＤOI: http://dx.doi.org/10.12795/elia.2018.i18.08 
Pajares, M. F. (1992). Teachers' beliefs and educational research: Cleaning up a messy construct. Review of educational research, 62(3), 307-332.

Reves, T., \& Medgyes, P. (1994). The non-native English speaking EFL/ESL teacher's self-image: An international survey. System, 22(3), 353-367.

Robertson, M., Macdonald, S., Starks, D., \& Nicholas, H. (2018). Enabling change in EFL teachers' ideologies about grammar and grammar teaching through alternative pedagogies. System, 72, 75-84.

Satar, H. M., \& Akcan, S. (2018). Pre-service EFL teachers' online participation, interaction, and social presence. Language Learning \& Technology, 22(1), 157-183. https//dx.doi.org/10125/44586

Scott, M. (2012). WordSmith Tools. A software program.

Singhal, M. (1998). Computer mediated communication (CMC): Technology for enhancing foreign language/culture education. On-Call, 12 (1), 10-15.

Spada, N. (1997). Form-focussed instruction and second language acquisition: A review of classroom and laboratory research. Language Teaching, 30(2), 73-87.

SPSS. (2009). Statistical Package for the Social Sciences. A software program by IBM

ELIA 18, 2018, pp. 183-212ＤOI: http://dx.doi.org/10.12795/elia.2018.i18.08 


\section{Appendix 1.}

1. Are you a teacher candidate? Yes No (circle the answer that applies to you).

2. Please, indicate your gender.

3. Please, indicate your current age.

4. What is your mother tongue/native language?

5. Do you speak any additional language at home? Which one/ones?

6. Do you use social media? Yes No (circle the answer that applies to you).

7. Which social media do you use? Facebook, Instagram, Twitter (circle the answer that applies to you. You may add any other social medium you use)

8. How often do you write on social media platforms in Norwegian? often sometimes never (circle the answer that applies to you)

9. How often do you write on social media platforms in English?: often sometimes never (circle the answer that applies to you)

10. Do you pay attention to grammar and spelling when you write on social media in Norwegian?: yes no (circle the answer that applies to you)

11. Do you pay attention to grammar and spelling when you write on social media in English?: yes no (circle the answer that applies to you)

12. Do you have problems with grammar and/or spelling when you write on social media in Norwegian?: yes no (circle the answer that applies to you)

13. Do you have problems with grammar and/or spelling when you write on social media in English?: yes no (circle the answer that applies to you)

First version received: July, 2018

Final version accepted: September, 2018

ELIA 18, 2018, pp. 183-212～DOI: http://dx.doi.org/10.12795/elia.2018.i18.08 